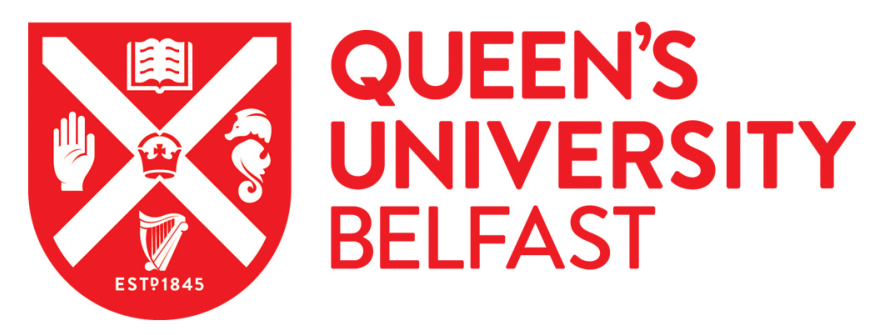

\title{
Older victims of crime: Vulnerability, resilience and access to procedural justice
}

Brown, K. J., \& Gordon, F. (2019). Older victims of crime: Vulnerability, resilience and access to procedural justice. International Review of Victimology, 25(2), 201-221. https://doi.org/10.1177/0269758018791426

Published in:

International Review of Victimology

Document Version:

Peer reviewed version

Queen's University Belfast - Research Portal:

Link to publication record in Queen's University Belfast Research Portal

Publisher rights

(C) 2018 The Authors.

This work is made available online in accordance with the publisher's policies. Please refer to any applicable terms of use of the publisher.

\section{General rights}

Copyright for the publications made accessible via the Queen's University Belfast Research Portal is retained by the author(s) and / or other copyright owners and it is a condition of accessing these publications that users recognise and abide by the legal requirements associated with these rights.

Take down policy

The Research Portal is Queen's institutional repository that provides access to Queen's research output. Every effort has been made to ensure that content in the Research Portal does not infringe any person's rights, or applicable UK laws. If you discover content in the Research Portal that you believe breaches copyright or violates any law, please contact openaccess@qub.ac.uk. 


\title{
Older victims of crime: Vulnerability, resilience and access to procedural justice
}

Kevin J. Brown and Faith Gordon

\begin{abstract}
This article provides the first comprehensive examination of the phenomenon of unequal access to procedural justice for older victims of crime. It analyses quantitative and qualitative data exploring the interactions of older people with the criminal justice system of Northern Ireland. It identifies that older victims of crime are less likely to have a successful crime outcome (known as 'detection' or 'clear-up' in other jurisdictions) to their case when compared to other adults. The results provide evidence of a system failing to adequately take into account additional vulnerabilities that disproportionately impact on older victims' ability to engage with the justice process. There is an analysis of the relationships between vulnerability, resilience and access to justice. The current conceptual understanding of vulnerability as applied to older people within the justice system is challenged. The findings are relevant for researchers and policy-makers in the United Kingdom, Ireland and further afield concerned with the treatment of older and vulnerable victims by the justice system.
\end{abstract}

Keywords Older people, aging, crime, victimization, resilience, vulnerability

There is an increasing consensus, nationally and internationally, in academic literature and policy discourse, that a focus of criminal justice systems should be to improve the experience of victims (Doak, 2014). Numerous proposals have been suggested and implemented to enact this goal, with particular consideration given to the needs of vulnerable victims (Department of Justice, 2015; Ministry of Justice, 2015). Within this context, increasing attention has begun to be paid by academics and policy-makers to the experiences of older victims of crime (Bows and Westmarland, 2017; Clarke et al., 2016; Commissioner for Older People in Northern Ireland, 2016). This article contributes to this literature through an analysis, incorporating qualitative and quantitative data, that explores the extent to which older victims of crime have access to justice in Northern Ireland.

Recently, concerns have been raised by the Commissioner for Older People in Northern Ireland (COPNI) (2014) and the Northern Ireland Policing Board $(2015 ; 2016)$ about the handling of cases in the jurisdiction involving older victims of crime. In response, research by Brown and Gordon (2018) conducted on behalf of COPNI found deficiencies in the criminal process that obstruct access to justice for older people. Of particular concern has been the finding that crimes involving older victims have a lower crime outcome rate than cases involving younger adult victims. The precise meaning of crime outcome rates, sometimes referred to as 'detection' or 'clear-up' rates in other jurisdictions, will 
be explored later in the article. In brief, it is a measure of the percentage of recorded reports of crime in which a suspect is identified and faces proceedings in a criminal court or an alternative disposal such as a fixed penalty or restorative justice. Therefore, a finding of a lower crime outcome rate for older age categories of victims means older people who report crimes to the police are less likely than other adults to see their case reach a sanctioned outcome. It is an important indicator of the extent to which older victims have substantive access to justice in Northern Ireland. The outcome rate findings from this study are unique as Northern Ireland is the only known jurisdiction to gather and make available information on outcome (or comparable) rates by age of the victim. Based on these research findings, this article provides the first academic analysis of the differences in crime outcomes between older and younger victims. The article critically explores the factors contributing to these differences. This includes the failure to recognise increased risks of vulnerability and lower resilience levels amongst the older population and to subsequently adequately support vulnerable older adults on their journey through the justice system. The findings of this study are relevant not only for Northern Ireland, but further afield in the UK, Ireland and globally as they identify issues that may be replicated, but undocumented elsewhere.

This study is 'interested in the...ways in which older victims (as opposed to younger victims) are perceived, handled, studied and treated' (Payne, 2005, p.vii) by the criminal justice system. Therefore, rather than simply classifying the 'elderly' as a discrete category of victims, this study has been led by the data in determining what age ranges to include within the older victim category. As will be discussed, evidence of depreciating access to justice in Northern Ireland is in evidence for victims aged 55+ with those within the oldest age categories having the lowest recorded levels of access.

The article will first explore the concept of access to procedural justice for older victims, before turning to the methodology underpinning the research study. It then explores the outcome rate data for Northern Ireland as a measure of access to procedural justice over the previous decade identifying how older victims of crime are less likely to have a successful outcome to their case than younger adults. The reasons behind the differences in outcome by age of victim are then explored, before turning to a final discussion on reforms that could be introduced to seek to improve access to justice for older victims of crime.

\section{The concept of access to justice for older victims}

This paper examines access to procedural justice for older victims of crime. Over the last three decades there has been a focus, nationally and internationally, on ensuring equality of treatment of victims when it comes to procedural rights. This includes the absence of direct or indirect discrimination within the justice system based on victims' protected characteristics, such as age, race, gender, nationality or sexual orientation. By focussing on procedural justice, this article is not seeking to downplay the importance of achieving wider social justice for older people who experience harm within society (Tang and Lee, 2006). 
A leading source of procedural rights in European nations is the 2012 European Union (EU) Directive establishing minimum rights, support and protection of victims of crime (hereafter referred to as the '2012 Directive'). According to the preamble of the 2012 EU Directive, equal access to justice is a fundamental right of all EU citizens. Equal access requires that all victims should be treated with dignity and respect (2012 Directive Article 1). This includes the absence of malice or prejudice in the treatment of victims by practitioners (2012 Directive Article 1). The enshrinement of such protections in law is an acknowledgement of the history of discrimination against particular categories of policed communities including travellers (Mulcahy, 2012), the black and minority ethnic community (Sharp and Atherton, 2007), and the lesbian, gay, bisexual and transgender/transsexual-plus communities (Williams and Robinson, 2004). Prior to this study, to our knowledge, there has been no substantive published research study into potential discrimination against older victims of crime.

Research into other aspects of societal life has found older people often do not have equal access to services or support. Discrimination against older people has been found in the provision of health, social care, education, training and employment (Hanson, 2014; Ben-Harush et al., 2017; Sargeant, 2016; Swift et al., 2016). Discrimination is driven by widespread societal prejudice, stereotyping of the older population and a failure to sufficiently accommodate the needs of older people (Ray et al., 2006; Swift et al., 2016).

Treating all victims in the same manner provides prima facie equal access, but it does not necessarily provide fair access, as some victims need additional support to overcome individual or structural obstacles to participation (2012 Directive Article 22). Guaranteeing fair access requires systems that adequately support vulnerable victims on their journey through the criminal justice process (Burton et al., 2007). This includes tailored support mechanisms to enable a victim to provide their best evidence, for example through the use of intermediaries to assist victims with communication difficulties (Burton et al., 2007). It involves taking steps to reduce the risk of secondary victimisation by eliminating unnecessary stress or trauma caused to victims when they participate in the justice system (2012 Directive paras 53-59). Such stress can be caused by the proceedings themselves or by the risk of further (re-)victimisation (Orth, 2002; Parsons and Bergin, 2010). Some victims will be at greater risk of such secondary victimisation than others due to vulnerabilities or the circumstances of the crime (Campbell and Raja, 1999; Herman, 2003). A failure to adequately deal with secondary victimisation not only leads to the risk of further traumatisation of victims, it also serves to discourage victims from participating in the justice system (Maddox et al., 2011; Taylor and Gassner, 2010). Northern Ireland has an established legal framework of special measures for victims categorised as vulnerable or intimidated found within The Criminal Evidence (Northern Ireland) Order 1999. The Northern Irish framework is very similar to that found in England and Wales (under the Youth Justice and Criminal Evidence Act 1999 Part 3).

A key feature of the 2012 Directive is that it places an onus on the agencies of the criminal justice system, predominately the police as the public facing agency, to 
pro-actively and in a timely fashion conduct assessments of victims' needs. These assessments should establish victims' levels of vulnerability and the additional support measures, if any, that the state should put in place to reduce the risk of secondary victimisation, intimidation or retaliation (Art. 22). The personal characteristics and circumstance of victims that make them susceptible to harm, intimidation or further victimisation should be taken into consideration when assessments of need are conducted (Art. 22).

As with other European jurisdictions, Northern Ireland has introduced legislative, policy and practice reforms to comply with the 2012 Directive (see Brown and Gordon, 2018). At least on paper, victim vulnerability is much more in the foreground than previously. This includes the introduction of a statutory Victims' Charter that came into force in 2015 (Department of Justice, 2015). This sets out entitlements and services that victims of crime in Northern Ireland can expect to receive from criminal justice agencies. It promotes fair treatment, adequate assessments of victims' needs and the provision of appropriate support (Department of Justice, 2015). The Charter makes reference to older people once in the 92-page document in regard to the identification of intimidated witnesses (Department of Justice, 2015 para. 48). The EU Directive (recital 66) also makes one reference to older people in the preamble when it states that its purpose is to promote 'the principle of equality between women and men, the rights of the child, the elderly and persons with disabilities, and the right to a fair trial'. The remainder of this article discusses empirical research findings that demonstrate the necessity for greater emphasis to be placed on the needs of older people as victims of crime in the pursuit of equality of access to procedural justice.

\section{Methodology}

The study applies a mixed methodology, combining analysis of quantitative and qualitative data. This allowed for an exploration of key research questions that included: What are the more common categories of crime reported to the police by older people in Northern Ireland? What is the likelihood a crime reported to the police by an older person will reach a sanction outcome? What factors might be impacting on the outcome rate? And how do the agencies of the criminal justice system (in particular the Police Service of Northern Ireland (PSNI) and Public Prosecution Service (PPS)) respond to such crimes?

The PSNI (2018a, 2018b) publishes statistics on levels of recorded crime and the outcomes of those reports. Outcome rates are then calculated by the PSNI for different categories of crime. These statistics include details on the age of the complainant. The researchers analysed the statistics to explore what differences (if any) existed in outcome rates between older people and other adult complainants.

Having identified differences in outcome rate by age, qualitative research was conducted in 2016 (January to April) to explore the causes of those differences. 
Semi-structured interviews were conducted with older people who had been victims of crime. Eleven interviews were conducted in total. These interviews investigated the experiences of the participants. Following the interviews, two focus groups were conducted with older people, involving a total of 20 participants, to explore perceptions and experiences of crime and the criminal justice agencies.

A focus group with representatives from the PSNI was also conducted. This included eight participants who had various relevant roles within the service. The focus group investigated how PSNI officers handle cases involving older victims of crime.

Eight interviews were conducted with members of the PPS. The participants covered a range of roles and geographical localities in Northern Ireland. These interviews explored the role of the PPS in prosecuting cases involving older victims of crime.

Finally, the researchers interviewed two co-ordinators from Victim Support Northern Ireland. The participants between them in their roles covered a range of geographical localities, both rural and urban, in Northern Ireland. Both participants had extensive experience with the difficulties victims can encounter in the criminal justice system.

\section{Exploring evidence of unequal access to justice for older people}

Older victims make up a comparatively small proportion of victims in Northern Ireland according to both self-report victimisation surveys and recorded police statistics (Campbell, 2017; PSNI, 2018b). Official police statistics on recorded crime published by the PSNI (2018b) show in 2016/17 those aged 65+ made up $6.7 \%$ of the recorded offences with a victim, whilst constituting $16 \%$ of the population of Northern Ireland (NISRA, 2017). The reported crime rate differs significantly across the age groups. Police records (PSNI, 2018b) in Northern Ireland show there was an average of 37 recorded crimes per 1,000 of the population in 2016/17. The likelihood of recording a crime with the police was the highest for the 20-24 age group (73 per 1,000) and lowest for the $65+$ age group (15 per 1,000) (PSNI, 2018b). These statistics have shown a high level of consistency over the last decade, reflecting those found in many other jurisdictions that show older people are less likely to be victims of crime than younger adults (Central Statistics Office, 2016a; Office for National Statistics, 2017a; Scottish Government, 2018).

The headline figures mask differences in the profile of the types of offences that the various age categories are reporting. As shown in Table 1, in Northern Ireland crimes of theft, burglary and criminal damage make up a much higher proportion of recorded crimes for the older victim population, whilst crimes of violence against the person make up a significantly smaller proportion of crime for older victims than they do for younger adults (PSNI, 2018b). Older people are 
much less likely to be victims of crimes of violence than their younger contemporaries in Northern Ireland, a phenomenon that is replicated across the UK and internationally (Central Statistics Office, 2016a; Office for National Statistics, 2018; Scottish Government, 2018).

Table I. Percentage of recorded crime for different age categories of victim falling within particular offence categories in Northern Ireland (2016/17).

\begin{tabular}{lcccr}
\hline & $\begin{array}{c}\text { Crimes of violence against } \\
\text { the person (with and } \\
\text { without injury including } \\
\text { homicide) }\end{array}$ & $\begin{array}{c}\text { Crimes of theft and } \\
\text { criminal damage } \\
\text { (including burglary and } \\
\text { vehicular theft) }\end{array}$ & $\begin{array}{c}\text { Other crimes (includes } \\
\text { sexual offences, robbery } \\
\text { and crimes against } \\
\text { society) }\end{array}$ & $\begin{array}{c}\text { Total } \\
\text { crime } \\
\text { recorded }\end{array}$ \\
\hline All ages & $45 \%$ & $49 \%$ & $6 \%$ & $100 \%$ \\
Age 60-64 & $29 \%$ & $69 \%$ & $2 \%$ & $100 \%$ \\
Age 65+ & $16 \%$ & $80 \%$ & $4 \%$ & $100 \%$ \\
\hline
\end{tabular}

The statistical discussion thus far provides context, but does not tell us anything that is not well established in the literature already. The original aspect of this data analysis is based on the police crime outcome rate figures that we now turn to explore. The PSNI produce data on crime outcome rates in Northern Ireland for all crimes with an identifiable victim excluding the offence of fraud (PSNI, $2018 \mathrm{~b}) .{ }^{1}$ In basic terms, this is the rate at which recorded crimes achieve a successful police outcome. A successful police outcome is regarded as an accused/s being identified for the crime and being either charged/summoned for the offence, cautioned, the offence taken into consideration and a penalty notice being issued or the accused being given a discretionary disposal such as a referral to restorative justice (PSNI, 2018a). Outcome rate data is the best quantitative indicator available in Northern Ireland of the extent to which procedural justice for those who report a crime is likely to be obtained. It should be noted the outcomes relate only to pre-court proceedings and decisions. The methodology behind the calculation of outcome rates in Northern Ireland is based on the approach adopted in England and Wales (Home Office, 2017; PSNI, 2018a). Other jurisdictions publish similar data, although methodologies differ as does the nomenclature (Central Statistics Office, 2016a; Scottish Government, 2017; Smit et al. 2004). Where Northern Ireland appears to be unique is in gathering data that allow for outcome rates to be contrasted by age of complainant/victim (PSNI, 2018a). An analysis of the Northern Irish data thus provides original insights into how outcomes of police investigations can be impacted by the age of the victim.

A boxplot of the outcome rate statistics over the last decade for Northern Ireland broken-down by age of the victim, as represented in Figure 1, shows a nonlinear, monotonic relationship between age and outcome rate. There is a strong negative correlation between age and outcome rate over the period 2007/08$2016 / 17 .^{2}$ There are statistically significant differences in median outcome rate between age groups. ${ }^{3}$ 


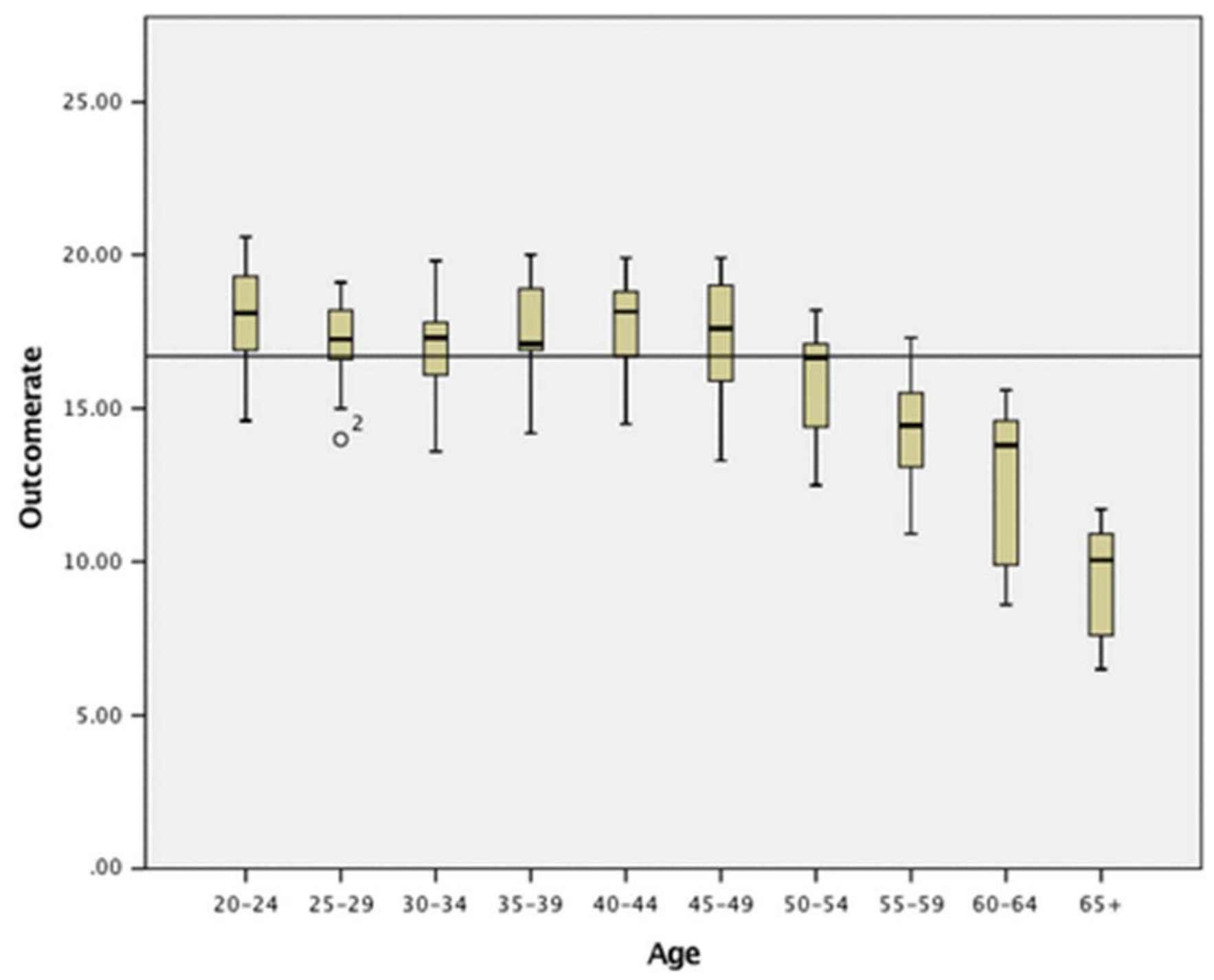

Figure 1. Boxplot of Crime Outcome Rates by Age in Northern Ireland 2007/82016/17 (Medium value of 16.7).

Visual inspection of the boxplot in Figure 1 shows a lower outcome rate amongst the older age categories. The three categories below the medium outcome rate for the relevant period are the 55-59, 60-64 and 65+ groups.

To explore the differences further, Figure 2 contrasts the annual outcome rate of a combined 20-54 age group with the older age groups of 55-59, 60-64 and 65+. Visual inspection of Figure 2 shows the 20-54 age group having a consistently higher outcome rate than the older age categories, although by varying amounts. Amongst the three older age groups in all but one year (2013/14), the outcome rates drop as we progress up the age categories. The 65+ age category always recorded the lowest crime outcome rate. 


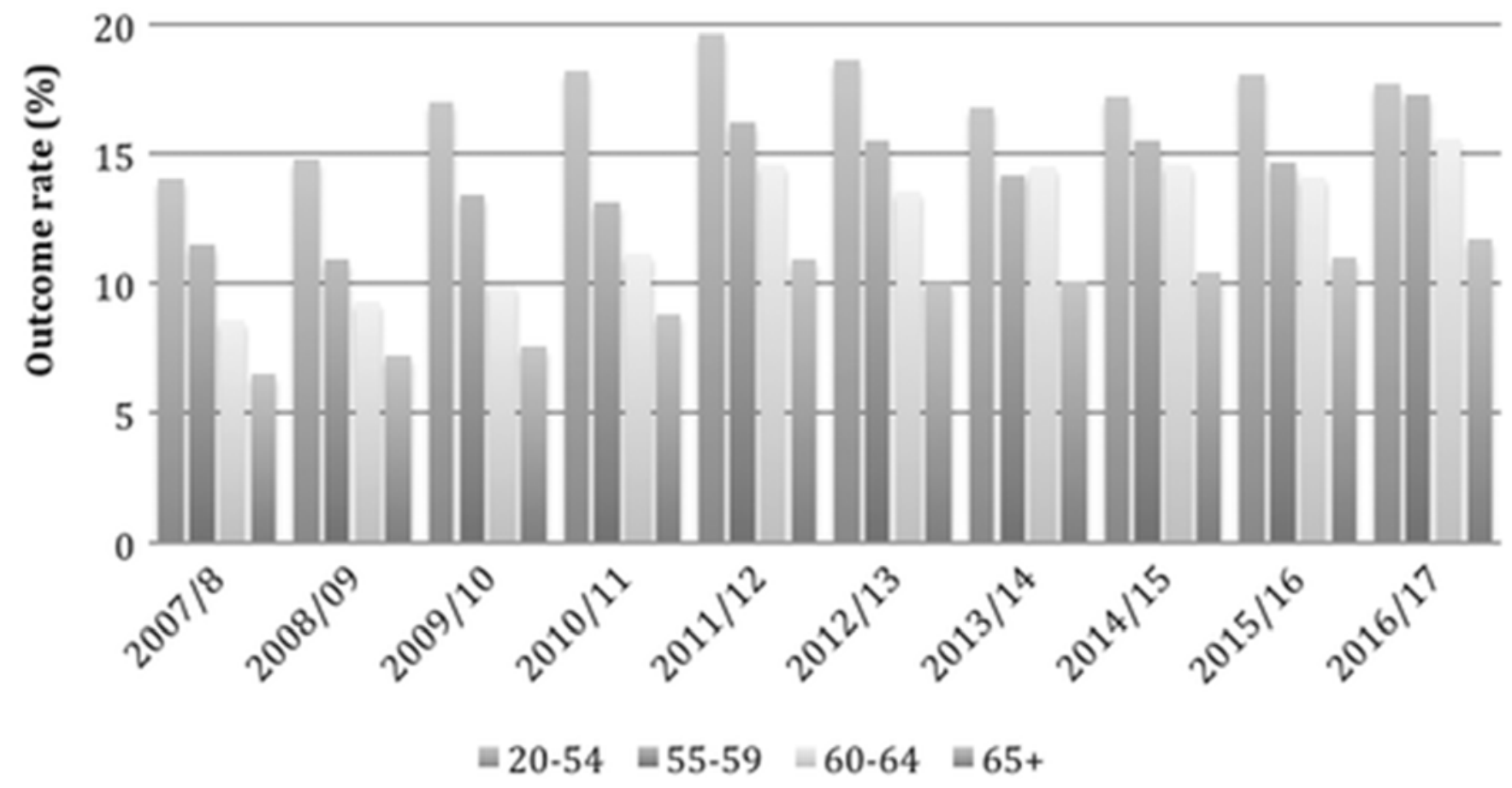

Figure 2. Crime outcome rates for various age categories 2007/8-2016/17.

A lower outcome rate for older adults in comparison to younger adults is evident across the 11 policing districts of Northern Ireland. The figures for 2016/17 are shown in Table 2 . They show a higher crime outcome rate for the 20-54 age group than the $55+, 60+$ and $65+$ categories in all districts. The figures show a pattern of outcome rate falling as the categories are narrowed from $55+$ to $60+$ and then to $65+$. The $65+$ is the category with the lowest crime outcome rate across nine of the 11 districts. The figures demonstrate that lower crime outcome rates for older complainants are found across Northern Ireland including in urban districts such as Belfast City and Derry City and Strabane, and more rural policing districts such as Fermanagh and Omagh and Mid Ulster. 
Table 2. Crime outcome rates by age of the complainant across the II policing districts of Northern Ireland in $2016 / 17$.

\begin{tabular}{lccccc}
\hline & $\begin{array}{c}\text { All ages } \\
\text { outcome } \\
\text { rate (\%) }\end{array}$ & $\begin{array}{c}\text { Age 20-54 } \\
\text { outcome } \\
\text { rate (\%) }\end{array}$ & $\begin{array}{c}\text { Age 55+ } \\
\text { outcome } \\
\text { rate (\%) }\end{array}$ & $\begin{array}{c}\text { Age 60+ } \\
\text { outcome } \\
\text { rate (\%) }\end{array}$ & $\begin{array}{l}\text { Age 65+ } \\
\text { outcome } \\
\text { rate (\%) }\end{array}$ \\
\hline A - Belfast City Policing & 13.1 & 13.2 & 12.6 & 11.4 & 10.3 \\
B - Lisburn and Castlereagh City & 22.2 & 23.7 & 17.6 & 15.9 & 13.9 \\
C- Ards and North Down & 19.2 & 20.6 & 16.8 & 16.1 & 13.2 \\
D - Newry, Mourne and Down & 19.1 & 20.0 & 13.4 & 10.6 & 10.2 \\
E - Armagh City, Banbridge and Craigavon & 19.1 & 20.8 & 14.0 & 12.2 & 12.1 \\
F- Mid Ulster & 20.0 & 21.4 & 13.7 & 14.6 & 13.6 \\
G - Fermanagh and Omagh & 21.0 & 22.5 & 15.3 & 12.9 & 11.3 \\
H- Derry City and Strabane & 20.2 & 20.9 & 16.9 & 13.6 & 11.6 \\
J- Causeway Coast and Glens & 19.5 & 19.5 & 18.8 & 19.1 & 18.2 \\
K- Mid and East Antrim & 15.7 & 17.6 & 11.1 & 8.5 & 6.6 \\
L- Antrim and Newtownabbey & 16.1 & 17.1 & 15.3 & 14.8 & 11.8 \\
Northern Ireland & 17.1 & 17.7 & 14.5 & 13.0 & 11.7 \\
\hline
\end{tabular}

A plausible hypothesis for the differences between older and younger adults in outcome rate is that the age groups are reporting different types of crimes and those different types of crime have differing outcome rates. To test this hypothesis, differences within offence categories by age of the victim were explored. Table 3provides a breakdown of mean outcome rates for various categories of offences by age category during the period 2007/08-2016/17. Other less frequently reported categories of crime, namely robbery and sexual offences, recorded insufficient numbers of crimes and outcomes to make any meaningful assessment of differences in outcome rate by age of complainant.

Table 3. Mean outcome rates for various categories of offences by age category 2007/08-2016/17.

\begin{tabular}{lcccrc}
\hline & $\begin{array}{c}\text { All ages } \\
\text { outcome } \\
\text { rate (\%) }\end{array}$ & $\begin{array}{c}\text { Age 20-54 } \\
\text { outcome } \\
\text { rate (\%) }\end{array}$ & $\begin{array}{c}\text { Age 55+ } \\
\text { outcome } \\
\text { rate (\%) }\end{array}$ & $\begin{array}{l}\text { Age 60+ } \\
\text { outcome } \\
\text { rate (\%) }\end{array}$ & $\begin{array}{l}\text { Age 65+ } \\
\text { outcome } \\
\text { rate (\%) }\end{array}$ \\
\hline All offences & 16.9 & 17.2 & 11.7 & 10.5 & 9.7 \\
Burglary & 9.3 & 9.9 & 7.8 & 7.3 & 6.8 \\
Criminal damage & 10.6 & 11.0 & 8.0 & 7.3 & 7.1 \\
Theft - vehicle offences & 17.0 & 17.3 & 15.0 & 14.2 & 14.1 \\
Other thefts & 6.0 & 5.9 & 5.8 & 5.6 & 5.4 \\
Violence (no injury) & 23.3 & 24.3 & 24.0 & 23.5 & 23.2 \\
Violence (with injury including homicide) & 29.9 & 29.7 & 35.0 & 35.8 & 37.8 \\
\hline
\end{tabular}

Analysis of the data finds statistically significantly lower outcome rates recorded over the last decade in the categories of burglary and criminal damage for cases where the victims were in the 55+,60+ and 65+ age groups when contrasted with the 20-54 age group. ${ }^{4}$ For the category of theft-vehicle offences, which includes theft of a vehicle and theft from a vehicle, there is a statistically significant lower outcome rate for the 65+ age group in comparison to the 20-54 
age category. There was not a statistically significant difference in outcome rate between the $20-54$ and the $55+$ or $60+$ groups although there was a consistent pattern of the older age categories having a lower outcome rate than the younger category across the 10 years. ${ }^{5}$ Analysis of the violence (no injury) category, whilst not finding statistically significant differences, does show a pattern over the last decade of a lower crime outcome rate for older victims in comparison to those aged 20-54. The 'other theft' category, which includes theft aside from fraud including theft from the person directly from the victim, but without the use of physical force against the victim, has very low outcome rates for all age groups making it difficult to discern, with any degree of certainty, a clear pattern of difference by age over the last decade. The only offence category with a statistically significantly higher outcome rate for older victims in comparison to those aged 20-54 was violence (with injury including homicide). ${ }^{6}$

This analysis of the statistics therefore demonstrates that crimes committed against older people are statistically less likely to have a successful police outcome than crimes committed against younger adults. This holds true across the 10 years of data. It also applies across all of the policing districts of Northern Ireland. This disparity is driven predominately by differences in outcome rates within offence categories that target property including burglary, criminal damage and vehicular theft that together made up 54\% of all crime recorded against victims aged $60+$ in $2016 / 17$. Only when it comes to the relatively uncommon (7\% of recorded offences against those aged 60+ in 2016/17) offence category of violence with harm (including homicide) are outcome rates higher for older victims than younger ones.

Comparative studies were sought to explore whether or not the statistical results on crime outcome rates and age found in Northern Ireland are replicated elsewhere or are an anomaly. Police forces in England and Wales operate under a similar criminal justice system and also use the concept of crime outcome rates, so a comparison with it and Northern Ireland would have particular value (Home Office, 2017). However, in personal communications (9 March 2016) with the Home Office it was confirmed that in England and Wales police forces do not record in a systematic manner the age of the complainant, meaning they are unable to break down crime outcome rate data by the age of the victim. In Scotland, statistical publications refer to 'crime clear-up' rates rather than outcome rates (Scottish Government, 2017). These are similar though not identical measures, but as in England and Wales the Scottish authorities are currently unable to break down their data by age of the victim (personal communication, 18 February 2016). In the Republic of Ireland, statistics on 'detection rates' are published (Central Statistics Office, 2016b). These data are not broken down by any characteristic of the victim. There is therefore no current way of knowing whether the outcome rate patterns found in Northern Ireland are also present in comparable jurisdictions on these islands. Indeed, no outcome/clear-up/detection rate data by age of the victim was found for any common law jurisdiction across the world. Given the similarities between the justice system of Northern Ireland and other common law jurisdictions, it is a plausible hypothesis that similar issues with age and outcome/detection/clear- 
up rate may exist. Given the implications for older victims of crime, research in other jurisdictions to establish if this is indeed the case would be valuable.

A consistent pattern of a lower crime outcome for older people for common offence categories is a cause for concern as it means older victims are less likely to obtain procedural justice in Northern Ireland than other age groups. A driver behind the commissioning of this project was concern expressed by the Northern Ireland Policing Board and COPNI (2014) about the lower crime outcome rate for older victims in relation to burglary. There is acknowledgement a problem exists, but to remedy it there needs to be an understanding of the cause/s of it. The qualitative aspect of the study explored explanations for the outcome rate differences by age and these are discussed in the following section.

\section{Exploring the reasons behind unequal access to justice}

The findings from the qualitative aspect of the study demonstrate that there are a number of factors contributing toward cases involving older victims having a lower crime outcome rate in Northern Ireland. This section is written up thematically, drawing upon these factors and new themes that emerged during the data collection period.

\section{- Vulnerability, resilience and the older population}

A theme that emerged from the data was that older victims are more likely to be vulnerable than younger adults with correspondingly lower levels of resilience to crime, which in turn impacted on their ability to engage with the criminal justice system without additional support. Both vulnerability and resilience are contested concepts; it is therefore important to unpack them (Walklate, 2011; Walklate et al., 2014). Much policy-making views victims or potential victims as vulnerable based on the attributes they possess such as being physically frail or of old age (Department of Justice 2015, p.24). Such an interpretation labels the 'elderly' as a vulnerable group. Vulnerability, however, can also be understood as relating to those who place themselves at greatest risk of victimisation (Sparks, 1982; Walklate, 2011). This definition leads to the labelling of younger adults who frequent public places at night as vulnerable, with older adults who remain at home at night as some of the least vulnerable in society. A third way of conceptualising vulnerability is to view those who are at greatest risk of harm from victimisation as vulnerable (Green, 2007; Sparks, 1982; Walklate, 2011). Related to this third interpretation is the concept of resilience. Resilience is a concept commonly utilised across a range of disciplines including medicine, psychology, business management, military studies and ecology (Walklate et al., 2014). According to Schoon (2006) resilience has been conceptualised in three different ways. The first is the ability to have a positive outcome despite experiencing adversity. The second is a continued ability to function positively in adverse circumstances. The third is the ability to recover from a trauma. 
In interviews and focus groups with older people, there was a rejection of the idea that older people as a group should be categorised as 'vulnerable'. Correspondingly there was a rejection of the view that all or even most older people lack resilience to cope with the trauma of being a victim of crime. Practitioners were also keen to emphasise that they did not hold such views. To label all older people as vulnerable or lacking resilience strips away the autonomy and individuality of people based on their age. However, both older participants and practitioners emphasised that in their experiences as people age they are increasingly likely to find a criminal infringement on their person or home traumatic and difficult to recover from. This reduced resilience in turn makes it more difficult for such older people to successfully engage with the justice system without additional support.

The traumatic impact a crime, whether violent or not, can have on an older person was referred to frequently by practitioners and older participants.

The complainants themselves are traumatised with any incident that happens, whether it's antisocial behaviour on the ground, or more directed towards them themselves, the burglaries and especially distraction burglaries leave them in a very bad state. (Police Focus Group Participant)

A wee woman, her son had just died and she was in her 80 s and two fellas came [to burgle the house]...the woman has Alzheimer's now but such a lovely person and it near wrecked her so it did. (Older People Focus Group Participant)

Crimes such as burglary have been shown to have significant adverse effects on victims with impacts on health, well-being and resilience. Recent statistics from the Crime Survey for England and Wales found in cases of burglary where there was effective entry, $57 \%$ of householders reported the crime had 'quite a lot' or 'very much' of an emotional impact on them (Office for National Statistics, 2017b, Table 3.10). Breaking this down further, one-third of householders stated it produced fear; $31 \%$ stated it caused a loss of confidence/heightened vulnerability; 23\% anxiety and panic attacks and 16\% depression (Office for National Statistics, 2017b, Table 3.10). These figures are for all ages and health backgrounds so we can speculate they are likely to be higher for more vulnerable adults.

Ill-health, both physical and mental, has been shown to reduce levels of resilience especially in older people (AgeUK, 2015; Wiles et al., 2012). In Northern Ireland as elsewhere, there is a higher prevalence of ill-health within the older population in comparison to other adults (Office of First Minister and Deputy First Minister, 2015). AgeUK (2017) produce a monthly bulletin on people in later life in the UK, summarising research and data from a range of sources. According to the August 2017 bulletin, 59\% of people aged 80 and over in the UK have a disability (AgeUK, 2017). Fourteen percent of those aged 65+, $35 \%$ of those aged $75+$ and $50 \%$ of those aged $90+$ have sight loss affecting their day-to-day living, whilst over $70 \%$ of those over 70 have some form of hearing loss (AgeUK, 2017). AgeUK (2017) also report it is estimated 850,000 people in the UK are living with dementia, with 808,000 of those people aged $65+$. 
Other factors that impact on resilience levels amongst older people include whether or not they live alone and the extent of any support networks they have available to them (Kharicha et al., 2007; Victor et al., 2000). Research has shown living alone is associated with heightened risk of loneliness, social isolation, illhealth and reduced resilience (Kharicha et al., 2007; Victor et al., 2000). In the UK data from the 2011 census, it was found $31 \%$ of the population aged 65+ were living alone (Office for National Statistics, 2013). In 2012, 40\% of all oneperson households in Northern Ireland were occupied by a person aged 65+ (NISRA, 2015). These figures are predicted to rise with changing population demographics due to increasing life expectancy (NISRA, 2015). During the interviews and focus groups with older people, being a victim of burglary was a source of particular distress because members of their demographic were more likely to live alone and to spend significant amounts of time in their homes.

Levels of social isolation and loneliness amongst the older population are influenced not only by living alone, but the extent to which there is access to support networks (Cattan et al., 2005). Research demonstrates that older people are more likely to be lonely or socially isolated than younger adults (Bolton et al., 2012). A UK-wide study found $17 \%$ of older people have less than weekly contact with family, friends and neighbours and 11\% having less than monthly contact (Victor et al., 2003). Older people are less likely to have the resilience derived from a support network to recover from the traumatic experience of being a victim of crime and then fully engage with the justice system.

The statistics on crime outcome rates for 'violence with injury' challenges the hypothesis of resilience playing a central role in the lower crime outcome rate for older people. One would expect crimes involving physical harm to have a greater traumatic impact on the victim, yet the crime outcome rate is higher for older victims in this offence category than younger adults. It is hypothesised here the reason for this difference is due to lower resilience levels being off-set because in cases of violent harm, victims are more likely to receive additional support (discussed later) as they journey through the justice system.

- A heightened reluctance or reticence on the part of older victims of crime to engage with the justice system

A theme that emerged from the qualitative research, which is connected to the emotional dynamics of resilience, was older complainants are more likely to be reticent than younger adults about engaging with the criminal justice system, past the initial stage of reporting a crime to the police. This reluctance does not mean older people have less confidence in the criminal justice system than other groups within society. Findings from the Northern Ireland Crime Survey show older people have some of the highest levels of confidence in the justice system although a minority of older respondents thought it effective (Cadogan and Campbell, 2014). Rather what the findings indicate is a greater reluctance amongst the older population to pursue a criminal complaint through the justice system. There are a number of reasons why this appears to be the case. 
Practitioners stated in their experience a significant number of older people were reluctant to engage with the justice process for fear of being a burden to officials, family members or others who make up their support network. A PSNI practitioner expressed it in the following terms,

My background is response policing. I'm very much the first face that these people will see...the over 60s when their confidence is hugely dented...they're not keen. They don't want to be a bother. They don't want to be a burden. (PSNI Focus Group Participant)

A heightened concern amongst the older population about being seen to be a burden on others is a well-documented social phenomenon, so it is unsurprising that it is a factor impacting on engagement with the criminal justice system (Cahill et al., 2009; Minichiello et al., 2000). Studies have shown older people are as likely to hold such stereotypes as younger people, a phenomenon that can be labelled a form of self-stereotyping (Minichiello et al., 2000; Swift et al., 2016). There is also a risk that practitioners, either explicitly or implicitly, convey a message to older victims they are in some way burdensome. Whilst the participants of this study did not express such views, ageist attitudes have been found to be prevalent in public-facing professions (Ben-Harush et al., 2017; Hanson, 2014; Swift et al., 2016).

Another reason for an increased reluctance is a fear of having to give evidence in court. This was identified by practitioners who participated in this research.

A lot of victims are very concerned about giving evidence in court, having to face the person again that has possibly either assaulted them or robbed from them. So that would be a huge concern for older people, because they've maybe never been through the process before. It may be the first time they've become a victim of a crime. So it's the thought of actually having to go to court, give evidence and have to look at this person again. (PSNI Focus Group Participant)

This fear of pursuing the case and giving evidence in court can be exacerbated by the individual circumstances of the case. Elder abuse where older people are targeted by someone they know such as a family member, neighbour or carer can pose particular difficulties, as acknowledged by a number of PSNI officers participating in the research.

These people have to live with it afterwards....Once the court case finishes they walk out of court, they have to go back to their lives and live either with these members of the public or members of family, and that's very daunting for people who are feeling vulnerable and victimised. (PSNI Focus Group Participant)

Elder abuse is defined by the World Health Organisation (2017) as 'a single or repeated act or lack of appropriate action, occurring within any relationship where there is an expectation of trust, which causes harm or distress to an 
older person'. A nationwide study by 0'Keeffe et al. in the UK in 2007 found $2.6 \%$ of people aged $66+$ living in private households experienced mistreatment by a family member, close friend or care worker in the past year. The figure increased to $4 \%$ when abuse by neighbours and acquaintances was added (O'Keeffe et al., 2007). The study found the likelihood of being a victim of elder abuse increased with age (3.5\% for those aged 66-74 in comparison to 5.5\% for those aged $85+$ ). Older people living alone were seven times more likely to report elder abuse than those who were not, whilst those reporting poor health were almost nine times more likely to report elder abuse than those reporting good health. Three-quarters of those reporting elder abuse said it had a serious or very serious impact on their lives, demonstrating the high impact on their health and well-being (O'Keeffe et al., 2007).

Even where the older person may not have a personal relationship with the culprit, there will be cases where culprits know where they live. This is pertinent in the case of burglaries that make up a higher proportion of the crimes reported to the PSNI by older victims than the general population (PSNI, 2018b). It also applies to reports of criminal damage or vehicular theft where it is the property of the older person that has been targeted. This fear of reprisals was raised by a number of PSNI officers. Older people who participated in the qualitative research also reported a fear of reprisals for giving evidence, with some basing this on their own personal experience.

[W] henever I went to court I had...the mirrors [of my car] smashed and the tyres were slashed. (Older Person Focus Group Participant).

Well the simple reason is that it could backfire and they come to your house and smash windows in or set fire to it or attack you. I would say that's why a lot of the elderly people wouldn't go [to court] (Older Person Focus Group Participant)

People of any age might be dissuaded from agreeing to give evidence in court if they are fearful of being targeted with reprisals. For an older person who lacks support networks, lives alone, and is suffering the trauma of the original crime, the thought of being targeted in such a manner may serve to deter.

A further complicating factor in the Northern Ireland context is the role paramilitary organisations continue to play within society (Campbell et al., 2016; Napier et al., 2017). A number of older people participating in the research talked of being reluctant to give evidence against individuals who were connected to paramilitaries for fear of reprisals. In contrast to this, for some other older participants, paramilitaries offered an alternative route to justice.

The irony is if something happened to me now I could go to the paramilitaries and I could have it settled within a couple of weeks...So it seems an irony where the police can't get anything done about it, can't even identify the person yet the community can find out who it is and have 
it sorted and it will never happen again. (Older Person Focus Group Participant)

People living in more socio-economically deprived areas are more likely to experience the influence of paramilitaries within their neighbourhoods than those living in more affluent areas, which means poverty and paramilitary pressures often go together (Campbell et al., 2016).

At a basic level, reluctance to participate in the criminal justice system is not predominately the fault of the PSNI or other agencies. However, without appropriate policies, procedures and practice in place to compensate for this heightened reluctance or reticence, older people will continue to have reduced access to justice in comparison to younger adults.

\section{- Vulnerability, resilience and evidential issues}

A theme that emerged as a partial explanation for the lower outcome rates for crimes involving older victims, is such cases tend to have a disproportionate amount of evidential complications. There cannot be a police sanction outcome without an identified suspect. Furthermore, to achieve a police sanction outcome, unless a suspect is willing to admit their guilt and accept a caution or alternative disposal, a police officer needs to be satisfied of a reasonable prospect of conviction prior to charging or the issuance of a summons (College of Policing, 2017). To obtain a conviction, unless there is a guilty plea, a court must be convinced beyond reasonable doubt that the defendant committed the crime.

Practitioners identified a number of issues that can make gathering sufficient evidence more difficult in cases involving older victims. As people age they are more likely than to have issues with sensory impairment and communication difficulties as well as deficiencies in memory recall. This means older victims are more prone to have difficulty providing witness testimony that would be of a standard to satisfy the evidential thresholds of the criminal justice system. Additional support mechanisms such as video testimony recorded at the time of the incident or the use of intermediaries to aid with communication have been proven to assist in such cases, but, as will be discussed, too often these measures are not being utilised (Cooper and Wurtzel, 2014).

A number of practitioners spoke of how, in their experience, some offenders target older people because they might have difficulty providing admissible evidence. Older people themselves also expressed concerns about offenders targeting vulnerable members of their age group. One example of a category of crime that involves targeting older people is distraction burglaries, during which the occupier of the house is deceived into letting the culprit into their home or property to commit acts of thefts (Lister and Wall, 2006; Elliston, 2002). Practitioners mentioned this type of crime as one in which it is difficult 
to gather sufficient evidence in order to identify suspects and prosecute. This is because of a lack of forensic evidence and the fact that culprits sometimes operate in organised gangs targeting older people in a particular neighbourhood before moving elsewhere.

PSNI officers in their experience reported that a further complication can be a delay between the crime being committed and the older person reporting it. For crimes involving elder abuse, the victim may not realise for some time their trust is being abused and when they do, they may find it difficult to report the culprit. If the abuse has been going on for some time when the crime is reported, it can be difficult to establish when a trusting relationship turned into an abusive one.

PSNI officers also reported older victims are less likely to be forthcoming with information because they are fearful of reprisals, or are embarrassed or ashamed about the circumstances of the offence in cases involving breaches of trust or deception.

I find a lot when you're dealing with the distraction burglaries they get extremely embarrassed. They believe they're foolish, and even to admit to police that they're foolish, never mind members of their family. They really don't even want to tell you the truth or the whole picture because of the embarrassment, and the way they are being deceived. (PSNI Focus Group Participant)

The added complications that can be encountered in gathering evidence in cases involving older people means practitioners may decide such cases are too difficult to proceed with. This then has a disproportionate impact on an older victim's ability to gain access to justice, as was identified by a Victim Support Officer.

It'll be the elderly person that suffers at the end of the day. They've gone through this trauma; they've had this burglary, they've had this criminal damage, they did the right thing, reported it to the police, given their statements and all of a sudden somebody's saying, 'We don't think you'll make a good witness so therefore we're not going to prosecute.' (Victim Support Officer)

There is a risk that ageist prejudice amongst the police and prosecution service is influencing decisions on the strength of evidence of cases involving older people. For example, a decision-maker may view older people as inherently less reliable witnesses. Whilst there is to date no evidence to confirm the prevalence of such views in the justice system, research has found supposedly evidence-based decision-making by professionals in health and social care is often influenced by such prejudices (Ben-Harush et al., 2017; Hanson, 2014; Swift et al., 2016). 
A key theme that emerged from the qualitative aspect of this research study, supported by the quantitative data, is older victims of crime in need of additional support are not always being correctly identified as vulnerable or intimidated. The ability to recognise and respond to vulnerability is a welldocumented failing of the criminal justice system in Northern Ireland (Criminal Justice Inspection Northern Ireland, 2006, 2012, 2015). The Criminal Justice Inspectorate of Northern Ireland $(2012 ; 2015)$ has spoken of a 'hierarchy of identification' of vulnerability that resonates with Burton et al.'s (2006) concept of a hierarchy of victims. Child witnesses and victims of sexual offences are more likely to be identified as being vulnerable compared to adult victims of other crimes. A Home Office study conducted in England and Wales in 2006 identified 24\% of witnesses as being either vulnerable or intimidated in contrast to the 3-6\% identified as such by the criminal justice system at that time (Burton et al., 2006). In 2012, the Inspectorate reported in their opinion in Northern Ireland fewer than half of all those who were vulnerable and intimidated were actually being correctly identified as such. In August 2016, a report by Her Majesty's Inspectorate of Constabulary (2016) reported in the year to March 2015 that the PSNI flagged 2\% of its cases as having a vulnerable victim. This contrasted with $10.7 \%$ in England and Wales (Her Majesty's Inspectorate of Constabulary, 2016). Such a large discrepancy provides evidence that there are significant problems in the identification of vulnerable and intimidated adults victims of crime in Northern Ireland.

Criminal justice policy in Northern Ireland, as elsewhere in the UK and Ireland, recognises some victims face additional difficulties when interacting with the criminal justice system because of personal circumstances or the type of crime to which they have been subject. To allow these victims to participate in the justice process and give their best evidence, additional support can be made available to assist them. Under Northern Irish criminal procedure, as with elsewhere in the United Kingdom, victims who meet particular criteria may be classified as 'vulnerable' and/or 'intimidated' (Department of Justice, 2015). This classification system acts as a gateway to additional support to be put in place to assist such victims or witnesses on their journey through the criminal justice system (Department of Justice, 2015).

The support available to victims or witnesses classified as vulnerable or intimidated depends on an assessment of their individual needs but can include the use of various special measures to aid with their giving of evidence. These are legislated for by the Criminal Evidence Order (Northern Ireland) 1999, henceforth referred to as the '1999 Order'. This includes allowing victims to give evidence via video-link from outside the courtroom or from behind a screen in the courtroom so they are shielded from the defendant (1999 Order Arts. 11 and 12). Video-recorded statements given to the police may be taken in appropriate cases and played in court in place of or in addition to the witness's testimony (although the witness will still need to 
be available for cross-examination at the court stage in most cases; 1999 Order Art. 15). Aids are available to assist those experiencing communication difficulties to provide evidence to the police, and if necessary, to the court (1999 Order Art. 18). A registered intermediary scheme is also available, providing victims with communication difficulties with the assistance of a trained individual to help them communicate with the various agencies (1999 Order Art. 17).

The definition of 'vulnerability' most commonly relied upon in the criminal justice system in Northern Ireland is that found in the legislation governing the use of special measures in court (1999 Order Art 4). It is the same as the definition used in England and Wales (Ministry of Justice, 2015, p.15). The 1999 Order Art. 4 states that victims and witnesses will be eligible for special measures if they fall into one of the following categories: they are under 18; they have a recognised mental disorder, significant impairment of intelligence and social functioning; and/or physical disability or physical disorder. This definition relies on a conceptual understanding of vulnerability as being based on mental and physical characteristics rather than the risk of victimisation or the risk of harm caused by victimisation. This fails to take into consideration factors that may be impacting on the resilience of a victim, such as the nature of the crime; a lack of support network; or mental or physical ill-health that does not reach the threshold of that outlined in the legislation.

To be classified as 'intimidated', the definition used in Northern Ireland requires that the quality of evidence of a victim or witness would be likely to be reduced because of fear or distress in relation to giving evidence (Department of Justice, 2015). The 1999 Order Art. 5 sets out a number of factors that the authorities should take into consideration when judging whether a witness is in fear or distress. These include the age of the witness, the social and cultural background of the victim, the domestic and employment circumstances of the victim, and the behaviour of the accused or the accused's family towards the victim. The Victims' Charter of Northern Ireland, providing further guidance, makes reference to 'a frail and older person' and those 'making allegations against professionals or carers' as potentially falling within the definition (Department of Justice, 2015, p.24). This category for access to special measures avoids the use of the term 'vulnerable' despite capturing aspects of vulnerability and resilience. The label of 'intimidation' is misleading, with both an ordinary everyday and criminal law understanding of the term meaning using threats or violence to instil fear in another. There is therefore a significant risk that victims will not view themselves as 'intimidated', despite potentially falling within the special measures definition. This is especially true in the context of Northern Ireland, where intimidation of communities by paramilitaries remains a significant and much discussed problem (Napier et al., 2017).

\section{Re-imagining the gateways to support for older victims of crime}


To improve access to justice for older victims of crime in Northern Ireland, there needs to be cultural and institutional change amongst the agencies of the criminal justice system - especially the police and prosecution service. The age-blind approach prevalent in policy documentation and amongst practitioners needs to be replaced with a more nuanced approach of accepting that older victims of crime are more likely to face impediments to access to justice and to require support to overcome these. This is not advocating a policy that treats all older people as vulnerable, but one that accepts that they are more likely to be so. Introducing training to raise awareness amongst practitioners of the diversity of needs within the older population would be an important first step. To complement training, policy documentation such as the Victims' Charter (Department of Justice, 2015) should be amended to make reference to the need for agencies to adopt an approach that is sensitive to increased need for support amongst the older population.

An impediment to better support for vulnerable older victims of crime in Northern Ireland is the out-dated and misleading definitions of 'vulnerable' and 'intimidated' found within the legislation governing access to special measures. These definitions cause confusion amongst practitioners and older victims, leading to a narrow interpretation of who should have access to special measures and other support. Policy-makers and legislators should work with stakeholders including older people to re-imagine and reform the terminology so that they act as more appropriate gateways to providing victims with the necessary support.

\section{Conclusion}

The criminal justice system in Northern Ireland is not providing equal access to procedural justice for older victims of crime. This is evidenced by an analysis of the crime outcome figures. This analysis demonstrates that for common categories of crime committed against older people, there are lower outcome rates than for similar crimes committed against younger adults. As this article illustrates, there are a number of factors contributing to this that disproportionately impact on the older population. Primary amongst these are increased levels of vulnerability, in the sense of an increased risk of harm from being a victim of crime, particularly one that relates to infringement of the person or the home. Connected to this is the phenomenon of lower levels of resilience in the older population, making it more difficult for victims to overcome the trauma of the criminal incident and endure the criminal justice process. Higher vulnerability and lower resilience levels combine with other factors to heighten reticence to engage with the justice system. These factors include the impact of societal prejudice, intimidation or the fear of it, a perception of not wanting to be a burden and the stress of giving evidence in court. The types of crime older people are disproportionately likely to be victim of also plays a role in reducing outcome rates. This includes elder abuse and distraction burglaries, which involve deliberately targeting older vulnerable adults. In addition, cases involving older vulnerable adults can be 
particularly challenging for practitioners when it comes to gathering sufficient evidence for a case to proceed to court.

The factors impacting on crime outcomes rates for older victims of crime can be mitigated by the provision of adequate support at the appropriate time. However, ongoing failings in the identification of vulnerable and intimidated adult victims on the part of the authorities in Northern Ireland leads to inadequate support being put in place. There needs to be an improvement in the provision of support for older people, including a re-imagining of the gateway concepts of vulnerability and intimidation currently used in Northern Ireland for access to special measures. Further procedural reforms are discussed in Brown and Gordon (2018).

Improving the crime outcome rate for older people would be a demonstration of the criminal justice system in Northern Ireland's adherence to the principles that all victims should be treated with dignity and given equal access to justice irrespective of age. Whilst this analysis has focused on Northern Ireland, it is reasonable to hypothesise that similar discrepancies in outcome (detection/clear-up) rate will be found in other jurisdictions, including those in in the rest of the United Kingdom, the Republic of Ireland and other common law jurisdictions. The findings contained within this study, the quantitative evidence-base and the voices of older victims, should be positioned as central in discussions and debate on future policy-making and academic research on vulnerable victims.

\section{Notes}

1.From 1 April 2015, Action Fraud took over responsibility from the PSNI for the central recording of fraud and cyber crime. Action Fraud is the UK's National Reporting Centre for fraud and cyber crime.

2.Spearman's Correlation $-r_{s}(98)=-0.643, p<0.0005$.

3.Kruskal-Wallis H test $-X^{2}(9)=40.767, p<0.0005$.

4.For criminal damage, independent student t-tests were run. Statistically significant differences were found amongst 20-54 and 55+, 60+, and 65+ groups $(p<0.0005)$. For burglary, Mann-Whitney tests were run (instead of student $t$-tests due to the presence of outliers). Statistically significant differences were found amongst 20-54 and 65+ groups $p<0.0005,20-54$ and $60+p<0.0005$, and $20-54$ and $55+p<0.01$.

5.Independent student $t$-tests were run. Statistically significant differences were found between 20-54 and 65+ groups $p=0.020$, although not between $20-54$ and $60+p=0.060$ or $20-54$ and $55+p=0.156$. 
6.Independent student $t$-tests were run. Statistically significant differences were found amongst $20-54$ and the $55+, 60+$ and $65+$ groups $(p<0.0005$

\section{Acknowledgments}

The authors are grateful to the Commissioner for Older People in Northern Ireland, the agencies and individuals who participated in the research. They wish to thank Jayne Hamilton for her work on an earlier version of the statistical analysis. They wish to thank Fiona Leverick and Anne-Marie Maclinden for their comments on earlier drafts of the paper. The views expressed are those of the authors.

\section{Funding}

This work was supported by the Commissioner for Older People in Northern Ireland. 


\section{References}

AgeUK (2015), Improving Later Life: Vulnerability and Resilience in Older People. AgeUK. ---(2017), Later Life in the United Kingdom. AgeUK.

Ben-Harush, A., Shiovitz-Ezra, S., Doron, I., Alon, S., Leibovitz, A., Golander, H., Haron, Y. And Ayalon, L. (2017), 'Ageism among physicians, nurses, and social workers: findings from a qualitative study', European Journal of Ageing, 14(1):39-48.

Bolton, M., Bowling, A., Burholt, V., Cattan, M., Cacioppo, J., Holt-Lunstad, J. And Walker, A. (2012), Loneliness-The State We're In. A Report Of Evidence Compiled For The Campaign To End Loneliness. AgeUK.

Bows H. And Westmarland, N. (2017), 'Rape Of Older People In The United Kingdom: Challenging The 'Real-Rape' Stereotype', British Journal Of Criminology, 57(1):1-17.

Brown, K. J. and Gordon, F. (2018), Improving Access to Justice For Older Victims of Crime: Older People as Victims of Crime and the Response of the Criminal Justice System in Northern Ireland. Commissioner for Older People in Northern Ireland. Burton, M., Evans R. and A. Sanders (2006), An Evaluation Of The Use Of Special Measures For Vulnerable And Intimidated Witnesses. Home Office.

-----(2007), 'Vulnerable And Intimidated Witnesses And The Adversarial Process In England And Wales', The International Journal Of Evidence \& Proof, 11(1):1-23. Cadogan, G. and Campbell, P. (2014), Perceptions Of Policing, Justice And Organised Crime: Findings From The 2011/12 And 2012/13 Northern Ireland Crime Surveys. DOI.

Cahill, E., Lewis, L.M., Barg, F.K. And Bogner, H.R. (2009), "You Don't Want To Burden Them" Older Adults' Views On Family Involvement In Care', Journal of Family Nursing, 15(3):295-317.

Campbell P. (2017), Experience Of Crime: Findings From The 2015/16 Northern Ireland Crime Survey. Department Of Justice.

Campbell R. and Raja, S. (1999), 'Secondary Victimization Of Rape Victims: Insights From Mental Health Professionals Who Treat Survivors Of Violence', Violence And Victims, 14(3): 261-275.

Campbell, K., Wilson, D. and Braithwaite, J.B. (2016), 'Ending Residual Paramilitary Domination In Northern Ireland? Restorative Economic And Social Inclusion Strategies' Regnet Research Paper No. 2016/123.

Central Statistics Office (2016a), Crime And Victimisation; Quarterly National Household Survey. CSO.

---(2016b), Review Of The Quality Of Crime Statistics 2016. CSO.

Clarke, A., Williams J., and Wydall S. (2016), 'Access To Justice For Victims/Survivors Of Elder Abuse: A Qualitative Study', Social Policy And Society, 15(2): 207-220.

College of Policing (2017), Prosecution And Case Management: Charging And Case Preparation. Available At Https://Www.App.College.Police.Uk/AppContent/Prosecution-And-Case-Management/Charging-And-Case-Preparation/ Commissioner for Older People in Northern Ireland (2014), An Analysis of The Clearance Rates For Crime Against Older People In Northern Ireland 2007/08 To 2012/13. COPNI. 
---(2016), Financial Abuse Of Older People In Northern Ireland: The Unsettling Truth. COPNI.

Cooper P. And Wurtzel D. (2014), 'Better The Second Time Around: Department Of Justice Registered Intermediaries Schemes And Lessons From England And Wales.' Northern Ireland Legal Quarterly 65: 39-61.

Criminal Justice Inspection Northern Ireland (2006), Avoidable Delay: A Thematic Inspection Of Delay In The Processing Of Criminal Cases In Northern Ireland. CJINI. ---(2012), The Use Of Special Measures In The Criminal Justice System In Northern Ireland. CJINI.

---(2015), The Care And Treatment Of Victims And Witnesses In The Criminal Justice System In Northern Ireland, Incorporating The Use Of Special Measures A Follow-Up Review Of Inspection Recommendations. CJINI.

Crown Prosecution Service (2009), Policy For Prosecuting Crimes Against Older People. CPS.

Department of Justice (2015), Victim Charter. DOI.

Department For Transport (2016), Road Use Statistics Great Britain 2016. Department For Transport.

Doak, J. (2014), 'Victims' Rights In The Criminal Justice System' In G. Brunsman And D. Weisburd (Eds), Encyclopaedia Of Criminology And Criminal Justice, 54975508. Springer.

Elliston, K. (2002), 'Tackling Distraction Burglaries And Their Impact On Older People's Health', Health And Hygiene, 23(2):16.

Equality Commission For Northern Ireland (2016), Age Discrimination Law In Northern Ireland. ECNI.

Hanson, R. (2014), 'Is Elderly Care Affected By Nurse Attitudes?: A Systematic Review', British Journal Of Nursing, 23(4):225 - 229.

Herman, J. L. (2003), 'The Mental Health Of Crime Victims: Impact of Legal Intervention', Journal Of Traumatic Stress, 16(2):159-166.

HMIC (2015), Witness For The Prosecution: Identifying Victim And Witness Vulnerability In Criminal Case Files. HMIC.

---(2016), Peel: Police Effectiveness (Vulnerability). HMIC.

Home Office (2017), Crime Outcomes In England And Wales: Year Ending March 2017. Home Office.

Kharicha, K., Iliffe, S., Harari, D., Swift, C., Gillmann, G. And Stuck, A.E. (2007), 'Health Risk Appraisal In Older People 1: Are Older People Living Alone An 'AtRisk' Group?' Br J Gen Pract 57(537): 71-276.

S. Lister And D. Wall (2006), 'Deconstructing Distraction Burglaries: An Ageist Offence?' In A. Wahidin And M. Cain (Eds) Ageing, Crime And Society. Willan Publishing. Chapter Seven.

Macnicol J. (2006), Age Discrimination: An Historical And Contemporary Analysis. Cambridge University Press.

Maddox, L. Lee, D. And Barker, C. (2011), 'Police Empathy and Victim PTSD as Potential Factors In Rape Case Attrition', Journal of Police and Criminal Psychology, 26(2):112-117.

Minichiello, V., Browne, J. And Kendig, H. (2000), 'Perceptions And Consequences Of Ageism: Views Of Older People', Ageing \& Society, 20(3):253-278.

Ministry Of Justice (2015), Code Of Practice For Victims Of Crime. Ministry of Justice. 
Mulcahy, A., (2012), 'Alright In Their Own Place': Policing And The Spatial Regulation Of Irish Travellers', Criminology \& Criminal Justice, 12(3):307-327.

Napier, R.J., Gallagher, B.J. And Wilson, D.S. (2017), 'An Imperfect Peace: Trends In Paramilitary Related Violence 20 Years After The Northern Ireland Ceasefires', Ulster Medical Journal, 86(2):99-102.

NISRA (2015), Northern Ireland Household Projections (2012-Based). NISRA. ---- (2017), NISRA Statistical Bulletin. NISRA.

Northern Ireland Policing Board (2015), Annual Policing Plan For Northern Ireland 2015-16. NIPD.

---(2016), Annual Policing Plan For Northern Ireland 2016-17. NIPD.

O'keeffe, M., Hills, A., Doyle, M., Mccreadie, C., Scholes, S., Constantine, R., Tinker, A., Manthorpe, J., Biggs, S. And Erens, B. (2007), Uk Study Of Abuse And Neglect of Older People: Prevalence Survey Report. Comic Relief and The Department of Health.

Office Of First Minister And Deputy First Minister (2015), A Profile Of Older People In Northern Ireland - Annual Update. OFMDFM.

Office For National Statistics (2013), Characteristics Of Older People: What Does The 2011 Census Tell Us About The "Oldest Old" Living In England \& Wales? ONS.

--- (2017a), The Nature Of Crime: Burglary. ONS.

--- (2017b), Crime in England and Wales: Annual Trend and Demographic Tables. ONS.

--- (2018), The nature of violent crime in England and Wales: year ending March 2017. ONS.

Orth, U. (2002), 'Secondary Victimization Of Crime Victims By Criminal Proceedings', Social Justice Research, 15(4): 313-325.

Parsons, J. And Bergin, T. (2010), 'The Impact Of Criminal Justice Involvement On Victims' Mental Health', Journal Of Traumatic Stress, 23(2):182-188.

Payne, B. K. (2005), Crime And Elder Abuse: An Integrated Perspective. Charles C. Thomas.

PSNI (2018a), User Guide To Police Recorded Crime Statistics In Northern Ireland. PSNI.

---(2018b), Financial Year Trends In Police Recorded Crime Dating Back To 1998/99: Victim Age And Gender Excel Spreadsheet. PSNI. Available At: Https://Www.Psni.Police.Uk/Inside-Psni/Statistics/Police-Recorded-CrimeStatistics/

--- (2018c), Police Recorded Crime Statistics. PSNI. Available Online At: Https://Www.Psni.Police.Uk/Inside-Psni/Statistics/Police-Recorded-CrimeStatistics/

Ray, S., Sharp, E. And Abrams, D. (2006), Age Discrimination 2006: A Benchmark For Public Attitudes. Age Concern England: Policy Unit.

Sargeant, M. (2016), Age Discrimination: Ageism In Employment And Service Provision. Routledge.

Schoon, I. (2006) Risk And Resilience: Adaptations In Changing Times. Cambridge University Press.

Scottish Government (2017), Recorded Crime In Scotland, 2016-17. Scottish Government.

-------- (2018), Scottish Crime And Justice Survey 2016/17: Main Findings. Scottish Government. 
Sharp D. And Atherton S. (2007), 'To Serve And Protect? The Experiences Of Policing In The Community Of Young People From Black And Other Ethnic Minority Groups', British Journal Of Criminology, 47(5):746-763.

Smit, P. R., Meijer, R. F. and Groen. P. J. (2004) 'Detection rates, an international comparison.' European Journal on Criminal Policy and Research 10(2): 225-253.

Sparks, R.F. (1982) Research On Victims Of Crime: Accomplishments, Issues, And New Directions. US Department Of Health And Human Services.

Swift, H.J., Abrams, D., Drury, L. And Lamont, R.A. (2016), The Perception of Ageing And Age Discrimination: Growing Older In The UK. British Medical Association.

Tang, K. and Lee, J. (2006), 'Global Social Justice for Older People: The Case for an International Convention on the Rights of Older People' British Journal of Social Work, 36(7): 1135-1150.

Taylor S. C. and Gassner L. (2010), 'Stemming The Flow: Challenges For Policing

Adult Sexual Assault With Regard To Attrition Rates And Under - Reporting Of

Sexual Offences, Police Practice And Research: An International Journal, 11(3):240-255.

Victor, C., Scambler, S., Bond, J. And Bowling, A. (2000), 'Being Alone In Later Life: Loneliness, Social Isolation And Living Alone' Reviews In Clinical, Gerontology, 10(4): 407-417.

Victor, C.R., Bond, J. And Bowling, A. (2003), Loneliness, Social Isolation And Living Alone In Later Life. Economic And Social Research Council.

Walklate, S. (2011), 'Reframing Criminal Victimization: Finding A Place For Vulnerability And Resilience', Theoretical Criminology 15(2):179-94.

Walklate S, McGarry R, Mythen G. (2014) 'Searching For Resilience: A Conceptual Excavation', Armed Forces \& Society 40(3):408-27.

Wiles, J.L., Wild, K., Kerse, N. And Allen, R.E. (2012), 'Resilience From The Point Of View Of Older People: 'There's Still Life Beyond A Funny Knee”, Social Science \& Medicine, 74(3):416-424.

Williams, M. L. And Robinson, A. L. (2004), 'Problems And Prospects With Policing The Lesbian, Gay And Bisexual Community In Wales', Policing And Society, 14(3):213-232.

World Health Organization (2017), Ageing And Life-Coure: Elder Abuse. Available At: Http://Www.Who.Int/Ageing/Projects/Elder_Abuse/En/

Yarrow, S. (2005), The Experiences Of Young Black Men As Victims Of Crime. Criminal Justice System Race Unit. 